\title{
Characteristics of glucose oxidase immobilized on Magnetic Chitosan Nanoparticles
}

\author{
Maryam EIN ALI AFJEH ${ }^{1}$, Rezvan POURAHMAD ${ }^{1 *}$ (D), Behrouz AKBARI-ADERGANI², Mehrdad AZIN ${ }^{3}$
}

\begin{abstract}
Immobilization process is used to facilitate the enzyme recovery and reusability. The aims of this study were to evaluate the effect of different amounts of chitosan on immobilization efficiency of Glucose Oxidase (GOX), pH effect on enzyme activity and changes of kinetic characteristics of enzyme immobilized on Magnetic Chitosan Nanoparticles (MCNP). GOX was immobilized on MCNP with cross bonds and Schiff base covalent connections. The sample with $0.3 \mathrm{~g}$ of chitosan had the highest immobilization efficiency (41.30\%). Morphology of nanoparticles was investigated by Scanning Electron Microscopy (SEM). Immobilization of GOX on magnetic nanoparticles was verified with Fourier Transform Infrared (FTIR). The effect of $\mathrm{pH}$ on enzyme activity was similar on both immobilized enzyme (IE) and free enzyme (FE). The evaluation of kinetic parameters for IE and FE has showed that the effectiveness factor was 0.45 . Generally, it could be concluded that magnetic nanoparticles with $0.3 \mathrm{~g}$ chitosan could provide a suitable medium for immobilization of GOX.
\end{abstract}

Keywords: chitosan nanoparticles; enzyme activity; glucose oxidase; immobilization efficiency; kinetic parameters.

Practical Application: In this study, glucose oxidase was immobilized on magnetic chitosan nanoparticles. This enzyme can be applied in food products especially meat and dairy products. The recovery of the immobilized enzyme from the complex medium by a foreign magnetic field is convenient and fast. Moreover, the use of immobilized enzyme is economically more feasible.

\section{Introduction}

Enzymes are biodegradable components which have less toxic effect in comparison to other prevalent industrial catalysers. On the other hand, they get much attention because they work in aquatic environment which eliminate threatening organic solvent environmentally (Sheldon, 2007).

GOX (oxido-reductase, EC: 1.1.3.4 $\beta$-D- glucose: oxygen 1 -) oxidizes $\beta$-D glucose to $\Delta$-gluconolactone by an oxygen molecule which consequently auto hydrolyzed to glucuronic acid and hydrogen peroxide (Hecht et al., 1993). One of the major products of this enzyme is glucuronic acid which is used in industries, like food industries. Glucuronic acid is a weak acid and naturally presents in juices and honey. GOX is also used in meat and dairy products and in bakery as sour dough and it is utilized as flavoring agent in syrups (Ramachandran et al., 2006). Some researchers used GOX in probiotic yogurt and reported that adding GOX could minimize oxidative stress and increase the viability of probiotic bacteria (Batista et al., 2015; Cruz et al., 2013). A lot of investigations have been conducted to immobilize GOX in different matrixes. These studies showed enhancing reusability, recovering, thermal and process stability, and improving the storage time (Blandino et al., 2001; Vikartovská et al., 2007). Immobilization of enzymes have been conducted by three major methods, including bonding to a surface, entrapment and cross linking (Sheldon, 2007; Jiang et al., 2012). Magnetic nanoparticles refer to particles with independent nature and magnetic element by size up to $100 \mathrm{~nm}$. These components have specific physicochemical properties which are dramatically different from bulk of the material (Osaka et al., 2006). Magnetic nanoparticles are considered more among all nanoparticles due to convenient separation with an outer magnetic field and their higher capacity to utilize for different purposes such as producing an advanced component, medical purposes, diagnostic methods, energy and food industries (Van Amerongen et al., 2005; Franzreb et al., 2006; Jeong et al., 2007). Toxicity and safety of the product must be of major concern in order to use magnetic nanoparticles in food. Therefore among magnetic nanoparticles, iron oxide nanoparticles, especially super paramagnetics, have the most application in food materials which is due to having not toxicity effect, good biocompatibility and no magnetic residual after magnetic field outage (Lu et al., 2007; Laurent et al., 2008; Cao et al., 2012). Recent investigations have been shown that magnetic nanoparticles are suitable substitutes for organic and mineral matrices in order to immobilize enzymes. Some of the advantages of this replacement are:

a) Simple, fast and low-cost separation of enzymes from complex medium while inducing magnetic field (Liu et al., 2011);

b) High enzyme loading capacity due to large special surface area;

c) No limitation in penetration into the solvents (Kim et al., 2006). some researchers investigated stability and activity improvement of GOX immobilized on modified iron oxide 
magnetic nanoparticles and reported that both IE and $\mathrm{FE}$ had the most activity at $30^{\circ} \mathrm{C}$ and $\mathrm{pH}=8$. Also, they demonstrated that covalent immobilization of enzymes caused little structural and conformational changes on nanoparticle (Abbasi et al., 2016). Chitosan refers to a group of linear polymers in which 2-actamid-2-deoxy- $\beta$-D-glucop yranosyl and 2 -amino-2-deoxy- $\beta$-glucopyranosyl monomers linked together through covalent $(1 \rightarrow 2)$ connection. Ratio of structural units of 2 -amino 2 -doxy- $\beta$-D- glocopyranose to total monomers in chitosan chain has been called Degree of Deacetylation (DD). When deacetylation of chitin occurs as much as the product completely dissolves in dilute solution of acetic acid (1-5\% V/V), the produced biopolymer calls chitosan (Sag \& Aktay, 2002). Chitosan gets much attention due to low-cost, stability, hydrophobicity and environmental compatibility (14). So, it is used in industrial and medical purposes such as wastewater treatment, enzyme inhibition and also as a carrier for control of drug release (Chiou \& Wu, 2004; Mi et al., 2000).

Some researchers investigated preparation of MCNP and immobilization of laccase. They reported that chitosan nanoparticles which prepared by reverse phase suspension methodology were spherical. Immobilization of laccase on chitosan nanoparticles were successful and showed good stability and recovery capacity (Fang et al., 2009). Some researchers showed that MCNP were a suitable carrier for immobilization of enzymes and the shape of nanoparticles was assessed by SEM which was spherical and semi-spherical. Kinetic parameters of $\mathrm{K}_{\mathrm{m}}$ and $\mathrm{V}_{\mathrm{m}}$ for FE were respectively $1.07 \mathrm{mM}$ and $29 / 43 \mathrm{U} / \mathrm{mg}$ and $1.29 \mathrm{mM}$ and $25 / 82 \mathrm{U} / \mathrm{mg}$ for lipase immobilized on chitosan magnetic nanoparticle (Ghadi et al., 2015). So far, no research has been conducted about immobilization of GOX on MCNP. So, the aims of this study were to evaluate the effect of different amounts of chitosan on immobilization efficiency of GOX, $\mathrm{pH}$ effect on enzyme activity and changes of kinetic characteristics of enzyme immobilized on MCNP.

\section{Materials and methods}

\subsection{Materials}

Glucose oxidase (EC 1.1.3.4) from Aspergillus niger (18.2 U/mg), chitosan (deacetylation degree 85\%) and Coomassie Brilliant Blue G-250 were purchased from Sigma Company (Japan). Deionized water, acetic acid (1\%), trisodium citrate, ammonia, glutaraldehyde, glacial acetic acid, chloride acid, $\mathrm{FeCl} 3.6 \mathrm{H} 2 \mathrm{O}$, $\mathrm{FeSo}_{4} \cdot 7 \mathrm{H} 2 \mathrm{O}$, sulfuric acid and phosphate buffer were obtained from Merck Company (Germany). Sodium hydroxide was purchased from Fleuca Company (Switzerland).

\subsection{Preparation of magnetic $\mathrm{Fe}_{3} \mathrm{O}_{4}$ nanoparticles}

$\mathrm{Fe}$ (III) $7.2 \mathrm{mM}$ and $\mathrm{Fe}$ (II) $3.6 \mathrm{mM}$ were prepared as described by Ghadi et al. (2015). An oxygen free vessel was used for final solution. $25 \mathrm{~mL}$ of above solutions were added to this vessel and then $\mathrm{N}_{2}$ was flown in it. After stirring for $30 \mathrm{~s}, 10 \mathrm{~mL}^{\circ} \mathrm{NH}_{3}$ was added to solution. The $\mathrm{pH}$ was adjusted to 9 . After $45 \mathrm{~min}$, the prepared nanoparticles were separated by a magnet. Synthesized
$\mathrm{Fe}_{3} \mathrm{O}_{4}$ nanoparticles were washed with distilled water at $\mathrm{pH} 7$. They were dried at $37-40^{\circ} \mathrm{C}$ (Ghadi et al., 2015).

\subsection{Preparation of magnetic nanoparticles solution}

$0.02 \mathrm{~g}$ of magnetic nanoparticles was dissolved in $50 \mathrm{~mL}$ deionized water and then $50 \mathrm{~mL}$ of $0.0054 \mathrm{M}$ trisodium citrate solution was added. The obtained solution was sonicated for $20 \mathrm{~min}$.

\subsection{Preparation of chitosan solution}

$0.1 \mathrm{~g}, 0.3 \mathrm{~g}$ and $0.5 \mathrm{~g}$ chitosan with average molecular weight and degree of deacetylation $85 \%$, were dissolved in $100 \mathrm{~mL}$ of $1 \%$ acetic acid solution separately and then stirred at $1000 \mathrm{rpm}$ for $25 \mathrm{~min}$ at $20^{\circ} \mathrm{C}$. The obtained clear solutions were sonicated (Amplitude 60, cycle 0.5 ) and $\mathrm{pH}$ was adjusted to 5 by addition of $\mathrm{HCl}$ or $\mathrm{NaOH}$ and then filtered $(0.2 \mu$ mesh).

\subsection{Coating of chitosan on magnetic iron oxide nanoparticles}

Coating of chitosan on on magnetic iron oxide nanoparticles was conducted as described by Ghadi et al. (2015).

\subsection{Enzyme immobilization}

Enzyme immobilization was conducted as described by Liu et al. (2012) with some modifications. $480 \mu \mathrm{L}$ of glutaraldehayde $(25 \% \mathrm{v} / \mathrm{v})$ was added to $50 \mathrm{~mL}$ of double distilled water and $2 \mathrm{~mL}$ magnetic chitosan nanoparticles solution was added under severe stirring. The surplus of glutaraldhyde was removed 3-7 times using shaker and centrifugation (10,000 x g, $20 \mathrm{~min})$ and then put in ice. $1 \mathrm{mg}$ glucose oxidase $(18.2 \mathrm{U} / \mathrm{mg})$ was dissolved in $10 \mathrm{~mL}$ phosphate buffer at $\mathrm{pH} 7.4$ and put in ice. The MCNP-glutaraldehyde solution was added to the enzyme solution under constant stirring at $1000 \mathrm{rpm}$.

\subsection{Measurement of total protein content}

$100 \mathrm{mg}$ of coomassie brilliant (CBB G-250) was dissolved in $50 \mathrm{~mL}$ of ethanol $95 \%$ in order to prepare Bradford reagent. After addition of $100 \mathrm{~mL}$ phosphoric acid $85 \%$, final volume was reached to 1 liter with distilled water. For experiment, $5 \mathrm{~mL}$ of reagent was transferred into the standard tubes, 50 microgram of sample or control was added then the absorption was read by spectrophotometer (Scinco S-3100, Korea) at $595 \mathrm{~nm}$ after $5 \mathrm{~min}$.

\subsection{Measurement of protein content (GOX) immobilized on chitosan nanoparticle}

For this measurement, total protein content utilized for immobilization was subtracted of protein content of supernatant after centrifugation and washing. Total immobilized protein was divided to total utilized protein for measuring immobilization efficiency (Ghadi et al., 2015) (Equation 1).

immobelization efficiency $\%=\frac{\text { total immobilized protein }}{\text { total utilized protein }} \times 100$ 


\subsection{Characterization}

Fourier transform infrared (FTIR) spectrophotometer (Nicolet Avatar-FTIR- FTIR-ATR, Thermo of USA) was used to characterize chemical bonds between magnetic chitosan nanoparticles and glucose oxidase.

The structure of $\mathrm{Fe}_{3} \mathrm{O}_{4}$ nanoparticles was determined using PHILIPS CM120 a transmission electron microscope (PHILIPS Co., Amsterdam, The Netherland). The grid size, accelerating voltage and magnification range were cu $200 \mathrm{mesh}, 120 \mathrm{kv}$ and 35X-750000X, respectively. The image recorder was GRACE, Gatan type 626. Morphology of samples after immobilization was obtained by using TESCAN MIRA3 a scanning electron microscope (Taiwan Co., LTD, Taipei, Taiwan) at room temperature $\left(21-23^{\circ} \mathrm{C}\right)$ in vacuum condition. The type of lenses and magnification range was 20X-500000X. MIRA TC was acquisition software that has been used in this study.

\subsection{Glucose oxidase activity}

Glucose oxidase activity was determined using a colorimetric assay based on the oxidation of o- dianisidine by a peroxidase coupled system (Vasileva \& Godjevargova, 2005; Zhu et al., 2005). One unit of enzyme causes the oxidation of one micromole of o-dianisidine per minute under the specified conditions $\left(\mathrm{T}=25^{\circ} \mathrm{C}, \mathrm{pH}\right.$ 6) (16).

\subsection{Kinetic parameters}

Kinetic parameters were determined at $25^{\circ} \mathrm{C}$ and $\mathrm{pH}$ 7.5. $\mathrm{K}_{\mathrm{m}}$ and $\mathrm{V}_{\mathrm{m}}$ values of free and immobilized glucose oxidase were obtained according to Lineweaver-Burk equation (Equation 2).

$\frac{1}{\mathrm{~V}}=\left(\frac{\mathrm{K}_{\mathrm{M}}}{\mathrm{V}_{\max }}\right) \frac{1}{[\mathrm{~S}]}+\frac{1}{\mathrm{~V}_{\max }}$

The ratio of $\mathrm{V}_{\max } / \mathrm{K}_{\mathrm{m}}$ determined the catalytic efficiency.

\subsection{Statistical analysis}

Experiment was conducted in single factor design with 3 replications which evaluated factor was chitosan amount in 3 levels (0.1, 0.3 and $0.5 \mathrm{~g})$. Analysis of variance (ANOVA) and Duncan's multiple range test were employed for analysis of results through SPSS (version 22) software.

\section{Result and discussion}

\subsection{Immobilization efficiency}

According to the Table 1, the amount of chitosan had significant influence on immobilization efficiency $(\mathrm{p}<0.05)$. The lowest immobilization efficiency was belonged to the sample with $0.1 \mathrm{~g}$ chitosan. The sample with $0.3 \mathrm{~g}$ chitosan had the highest immobilization efficiency. Appropriate amout of chitosan which was coated onto the magnetic iron oxide has a crucial role in developing efficient coating for subsequent functionalization and binding with glucose oxidase. The increase in amount of chitosan up to $3.0 \mathrm{~g}$ creates more complete and efficient coating for the magnetic particles. In higher doses of chitosan secondary nonbonding and free sites of chitosan can create for binding the enzyme that decrease its recovery for magnetic based nano particles.

TEM image (Figure 1) shows that magnetic nanoparticles are nanocrystaline. Their shape is approximately spherical. The results of TEM of $\mathrm{Fe}_{3} \mathrm{O}_{4}$ nanoparticles are in agreement with another study (Kaushik et al., 2008).

Surface morphology of MCNP was evaluated by SEM after immobilization of GOX (Figure 2a-c). Morphology of a uniform surface (Figure 2b) was in agreement with another study (Kaushik et al., 2008). Results showed that enzyme successfully immobilized on MCNP. Figure 3 indicates FTIR for MCNP before and after immobilization. Figure $3 \mathrm{a}$ indicates the prepared MCNP with $0.1 \mathrm{~g}$ chitosan before immobilization. The peaks at $1115 \mathrm{~cm}^{-1}$, and $1125 \mathrm{~cm}^{-1}$ are related to C-O-C stretching vibrations. The peak at $1380 \mathrm{~cm}^{-1}$ may be resulted from -C-O stretching vibration of primary alcoholic group of chitosan. The peak at $1570 \mathrm{~cm}^{-1}$ is probably related to N-H bending vibration. Figure $3 \mathrm{~b}$ shows the FTIR spectrum of GOX-MCNP ( $0.1 \mathrm{~g}$ chitosan) after immobilization. A new peak is appeared at $1649 \mathrm{~cm}^{-1}$ which is related to amide group of glucose oxidase. This peak confirms the glucose oxidase immobilization. Figure $3 c$ indicates the prepared MCNP with $0.3 \mathrm{~g}$ chitosan before immobilization. The peak around the $500 \mathrm{~cm}^{-1}$ can be related to vibrations of

Table 1. Immobilization efficiency (\%) in samples with various amounts of chitosan (mean $\pm \mathrm{SD})$.

\begin{tabular}{cc}
\hline Chitosan $(\mathrm{g})$ & Immobilization efficiency $(\%)$ \\
\hline 0.1 & $32.26 \pm 0.05^{\mathrm{c}}$ \\
0.3 & $41.30 \pm 0.28^{\mathrm{a}}$ \\
0.5 & $37.26 \pm 0.05^{\mathrm{b}}$ \\
\hline
\end{tabular}

Values with different letters differ significantly $(\mathrm{p}<0.05)$.

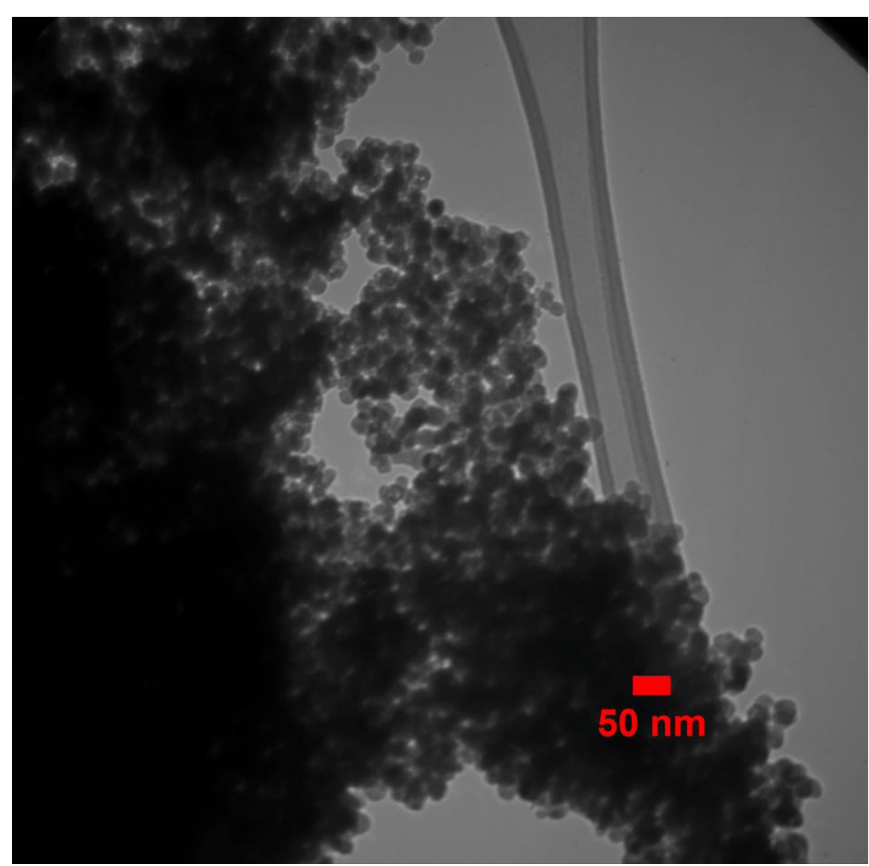

Figure 1. Transmission electron microscopy (TEM) of $\mathrm{Fe}_{3} \mathrm{O}_{4}$ nanoparticles. 
a

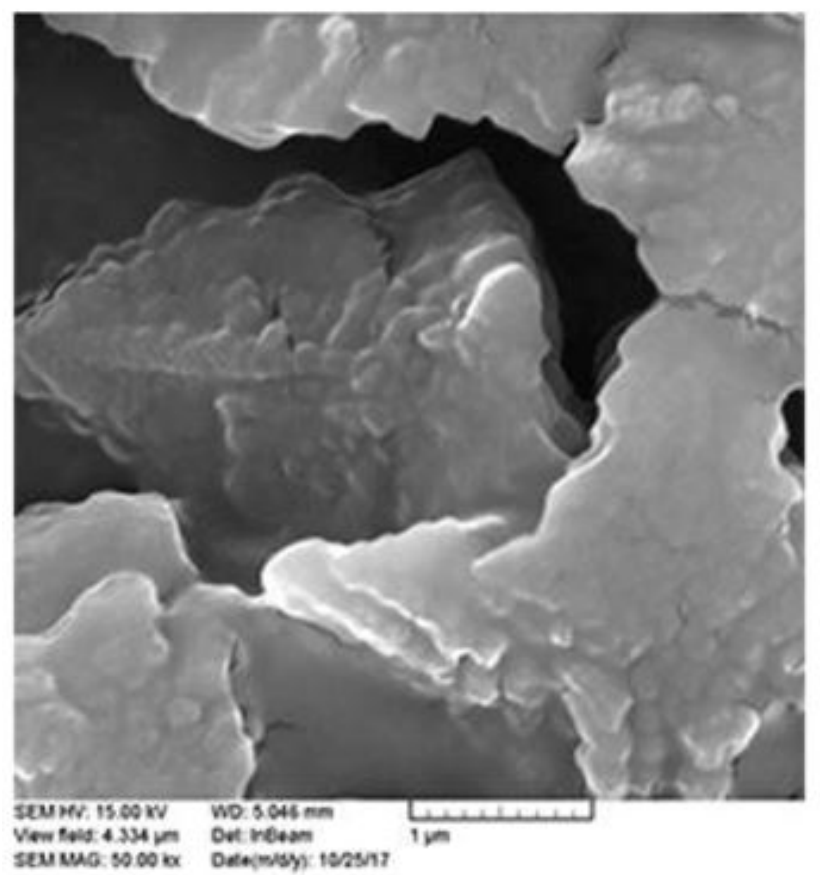

b

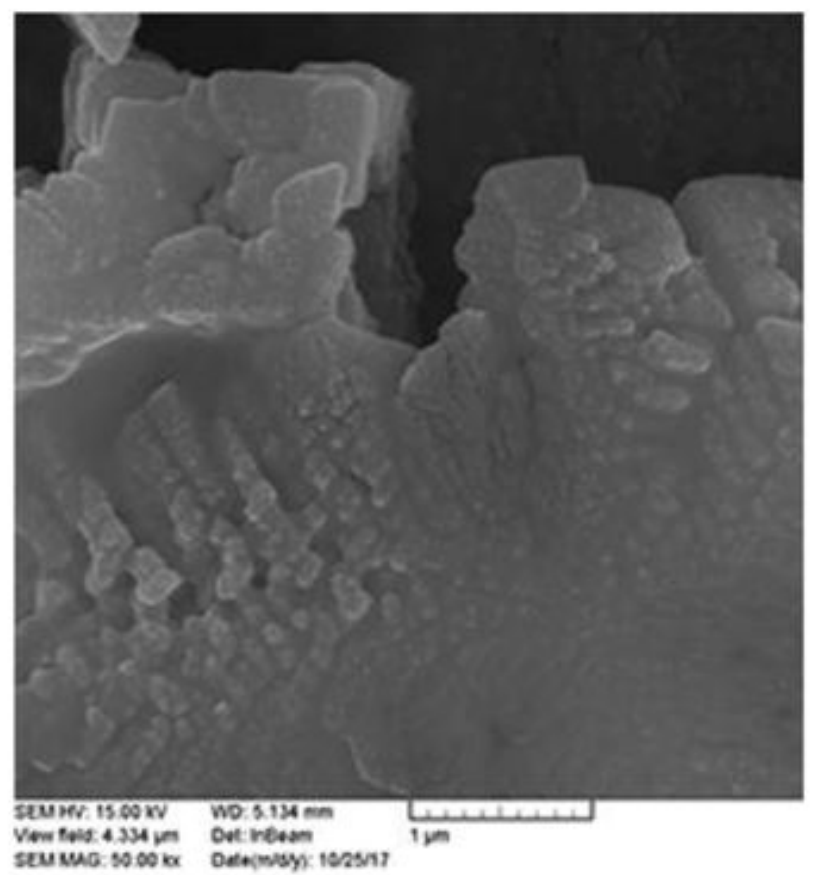

\section{C}

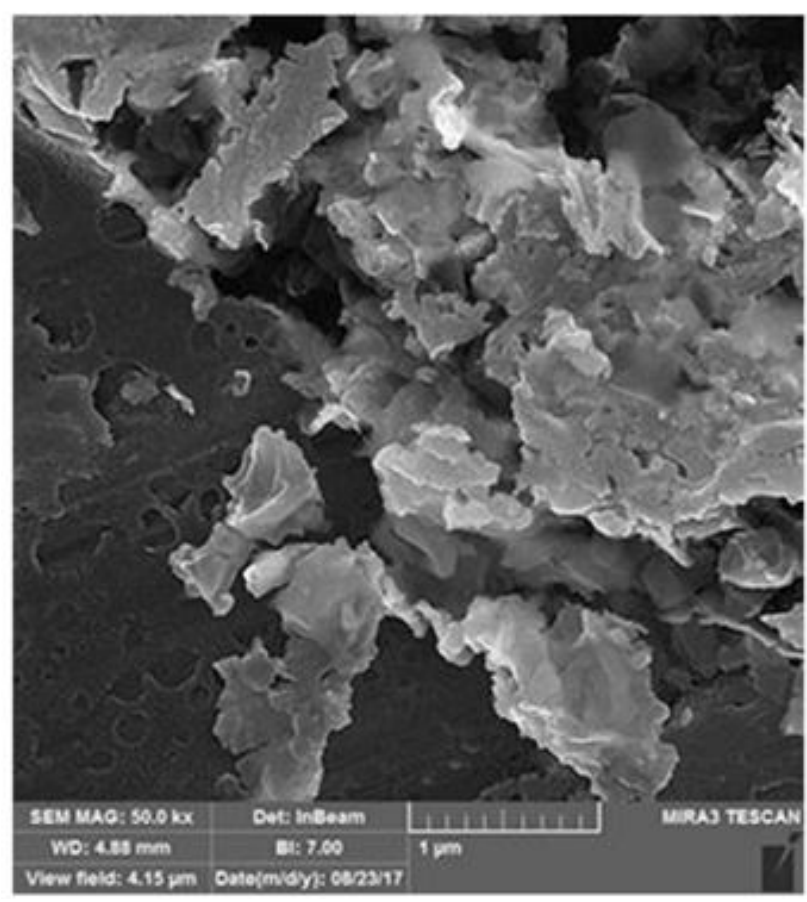

Figure 2. SEM images for GOX immobilized on MCNP with $0.1 \mathrm{~g}$ (a), $0.3 \mathrm{~g}$ (b) and $0.5 \mathrm{~g}$ (c). 
a

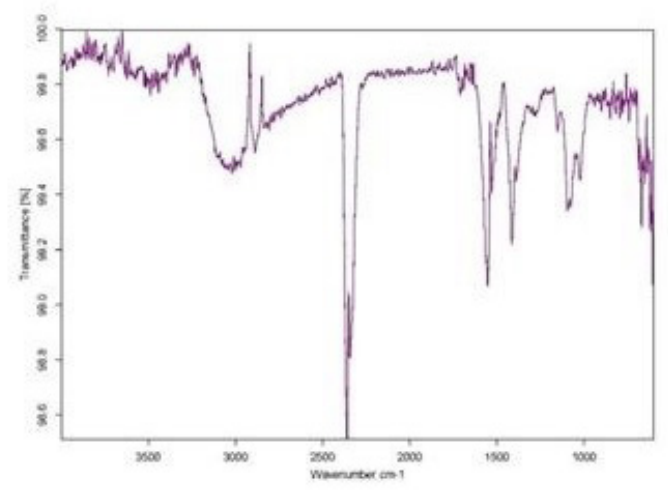

C

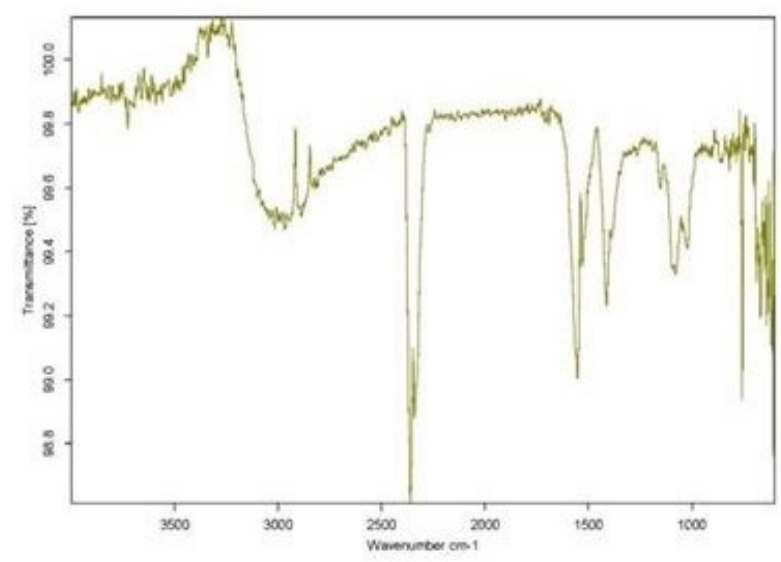

e

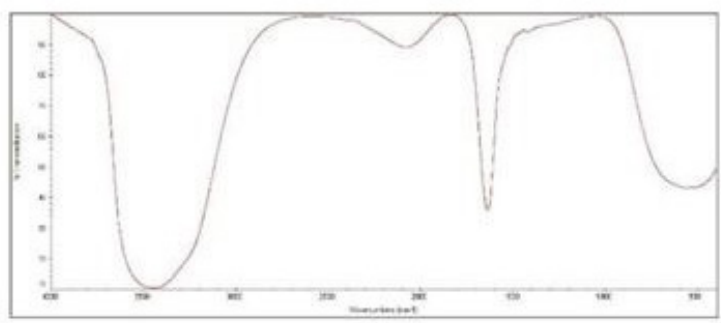

b

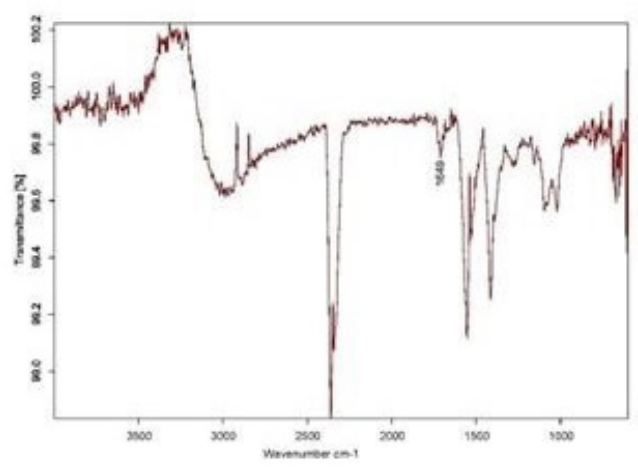

d

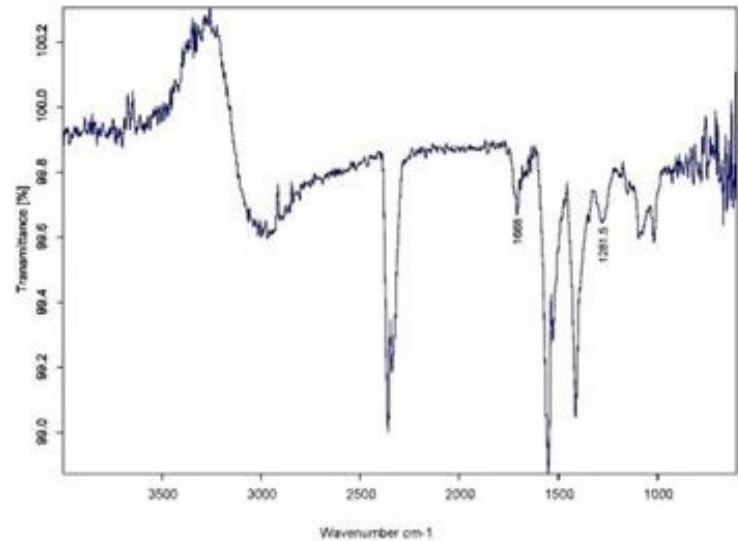

f

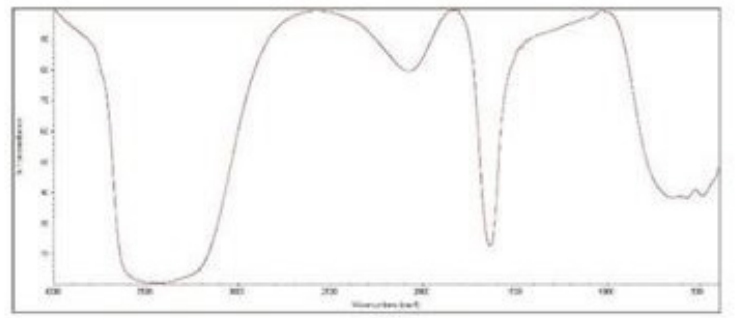

Figure 3. FTIR spectrum for prepared magnetic nanoparticles with $0.3 \mathrm{~g}$ chitosan before (a) and after immobilization (b), $0.1 \mathrm{~g}$ chitosan before (c) and after immobilization (d) and $0.5 \mathrm{~g}$ chitosan before (e) and after immobilization (f).

Fe-O that confirms the presence of magnetic nanoparticles. This result is in agreement with the finding of Moon et al. (2000). The peaks at $1060^{-1}$, and $1070 \mathrm{~cm}^{-1}$ are related to C-O-C stretching vibrations $\mathrm{cm}$ of chitosan. The peak at $1355 \mathrm{~cm}^{-1}$ may be resulted from -C-O stretching vibration of primary alcoholic group of chitosan. The peak at $1560 \mathrm{~cm}^{-1}$ is probably related to $\mathrm{N}-\mathrm{H}$ bending vibration. Figure $3 \mathrm{~d}$ shows the FTIR spectrum of GOX-MCNP ( $0.3 \mathrm{~g}$ chitosan) after immobilization. Two new peaks are appeared. The first peak at $1281.5 \mathrm{~cm}^{-1}$ is related to covalent joint of schiff's base between carbonyl group of glutaraldehyde and amine group. The second peak at $1668 \mathrm{~cm}^{-1}$ is resulted from amide group of glucose oxidase. These two peaks confirm the enzyme immobilization. Figure $3 e$ indicates the prepared MCNP with $0.5 \mathrm{~g}$ chitosan before immobilization. The broad peak at 3450.39 can be related to the hydroxyl stretching group and amine stretching group of chitosan. The peak at 1638.51 demonstrates 
the N-H bending group of amine. Glutaraldhyde acts as a cross linker, so after enzyme immobilization, the NHCO...CHO bonds are formed with amine groups of enzyme. Therefore, some amine groups are coated and some carboxyl groups of enzyme are exposed. The broad absorption peak of $\mathrm{OH}$ stretch of carboxylic acid group at $2700-3650 \mathrm{~cm}^{-1}$ (Figure 3f), shows that the glucose oxidase is successfully bound to the chitosan magnetic nanoparticles which is in agreement with a similar study (Ghadi et al., 2015).

\section{2 pH impact on activity of FE and IE on MCNP}

Figure 4 shows the effect of $\mathrm{pH}$ 3-10 on FE and IE. The trend of enzyme activity from $\mathrm{pH} 3$ to 8 was ascending. As shown, the activity of IE was higher than FE in acidic $\mathrm{pH}$ ( $\mathrm{pH}=3$ to 5).

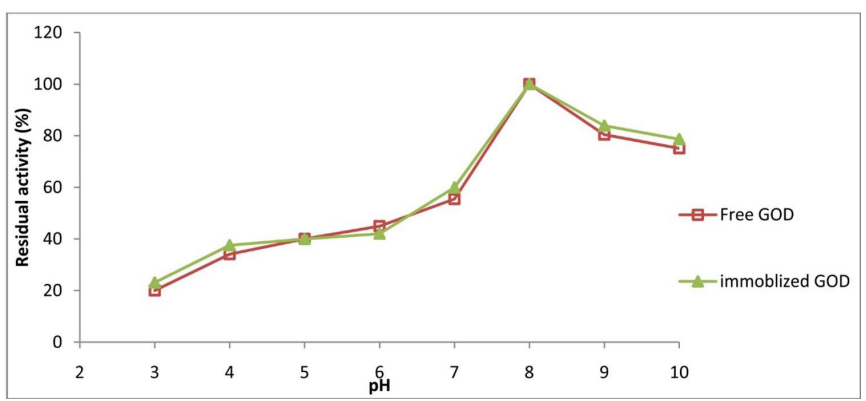

Figure 4. Effect of $\mathrm{pH}$ on free and immobilized glucose oxidase activity.
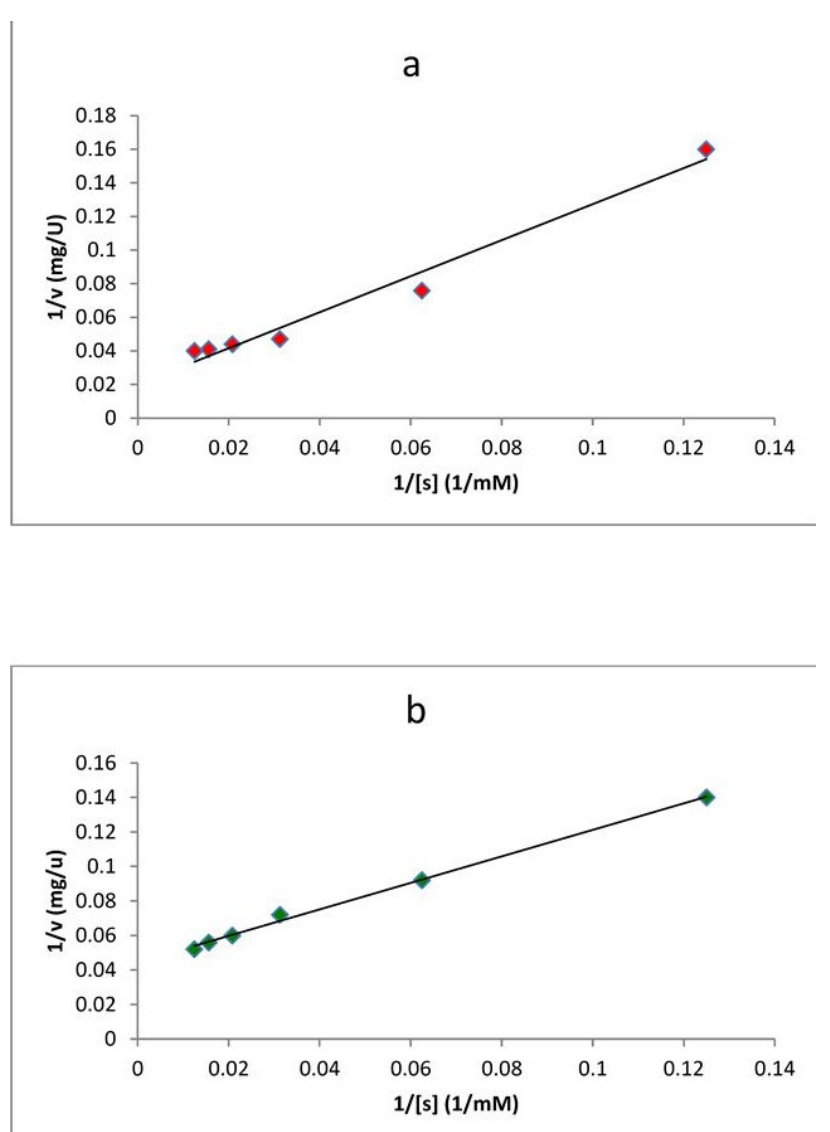

Figure 5. Lineweaver-burk plot of FE (a) and IE (b).
But the activity of free enzyme was higher than IE at $\mathrm{pH}=5-6$. In the $\mathrm{pH}$ range of 3-5 and 6-10, the activity of IE was higher than FE. In the present study, the optimal $\mathrm{pH}$ was 8 for free and immobilized enzyme. This value is according to previous studies (Isik et al., 2003; Ying et al., 2002). Effect of pH on free and immobilized enzyme activity is approximately similar, which seems that the enzyme's active site is unaffected by immobilization significantly (Li et al., 2007). However, the use of immobilized glucose oxidase in an extensive range of $\mathrm{pH}$ is possible.

\subsection{Kinetic parameters of FE and IE}

Lineweaver-burk plot of FE (a) and IE (b) is shown in Figure 5. The kinetic parameters were obtained $\mathrm{K}_{\mathrm{m}}=3.35 \mathrm{mM}$, $\mathrm{V}_{\mathrm{m}}=50 \mathrm{U} / \mathrm{mg}$ for free enzyme and $\mathrm{K}_{\mathrm{m}}=3.35 \mathrm{mM}, \mathrm{V}_{\mathrm{m}}=50 \mathrm{U} / \mathrm{mg}$ for immobilized glucose oxidase. The higher value of $\mathrm{K}_{\mathrm{m}}$ for immobilized glucose oxidase indicates its lower affinity to substrate compare with free enzyme (Huang et al., 2003). The effectiveness factor has been used as a comparative parameter for the immobilized system. The formula of EF is followed as (Shuler \& Kargi, 2002) (Equation 3):

Effectiveness factor $=\operatorname{Vmax}($ immobilized enzyme $) / \operatorname{Vmax}($ free enzyme $)$

The effectiveness factor was obtained 1 and 0.45 for free and immobilized enzyme, respectively. If the value of effectiveness factor is equal or lower than 1 , the immobilization process has an influence on the diffusion of substrate and product. Generally, enzymes lose some of their catalytic power when they are immobilized as the apparent $\mathrm{K}_{\mathrm{m}}$ values of immobilized enzymes are higher, and $\mathrm{V}_{\mathrm{m}}$ values are lower than those for free enzymes (Blandino et al., 2001; Yang et al., 2004). In this study, also the $\mathrm{K}_{\mathrm{m}}$ values of immobilized enzymes are higher, and $\mathrm{V}_{\mathrm{m}}$ values are lower than those for free enzymes.

\section{Conclusion}

According to the results of the present study, the sample with $0.3 \mathrm{~g}$ chitosan had the highest immobilization efficiency (41.30\%). Surface morphology of MCNP was observed by SEM after GOX immobilization. Immobilization of glucose oxidase on MCNPs was confirmed by FT-IR spectrometry. Effect of $\mathrm{pH}$ on free and immobilized enzyme activity is approximately similar, which seems that the enzyme's active site is unaffected by immobilization significantly. The use of immobilized glucose oxidase is possible in an extensive range of $\mathrm{pH}$. The investigation of kinetic parameters for IE and FE showed that the effectiveness factor was 0.45 . The $\mathrm{K}_{\mathrm{m}}$ values of immobilized enzymes are higher, and $\mathrm{V}_{\mathrm{m}}$ values are lower than those for free enzymes so it seems the enzymes lose some of their catalytic power after immobilization.

\section{References}

Abbasi, M., Amiri, R., Bordbar, A. K., Ranjbakhsh, E., \& Khosropour, A. R. (2016). Improvement of the stability and activity of immobilized glucose oxidase on modified iron oxide magnetic nanoparticles. Applied Surface Science, 364, 752-757. http://dx.doi.org/10.1016/j. apsusc.2015.12.120. 
Batista, A. L. D., Silva, R., Cappato, L. P., Almada, C. N., Garcia, R. K. A., Silva, M. C., Raices, R. S. L., Arellano, D. B., Sant'Ana, A. S., Conte, C. A. Jr., Freitas, M. Q., \& Cruz, A. G. (2015). Quality parameters of probiotic yogurt added to glucose oxidase compared to commercial products through microbiological, physical-chemical and metabolic activity analyses. Food Research International, 77, 627-635. http:// dx.doi.org/10.1016/j.foodres.2015.08.017.

Blandino, A., Macias, M., \& Cantero, D. (2001). Immobilization of glucose oxidase within calcium alginate gel capsules. Process Biochemistry, 36(7), 601-606. http://dx.doi.org/10.1016/S0032-9592(00)00240-5.

Cao, M., Li, Z., Wang, J., Ge, W., Yue, T., Li, R., Colvin, V. L., \& Yu, W. W. (2012). Food related applications of magnetic iron oxide nanoparticles: enzyme immobilization, protein purification, and food analysis. Trends in Food Science \& Technology, 27(1), 47-56. http://dx.doi.org/10.1016/j.tifs.2012.04.003.

Chiou, S. H., \& Wu, W. T. (2004). Immobilization of Candida rugosa lipase on chitosan with activation of the hydroxyl groups. Biomaterials, 25(2), 197-204. http://dx.doi.org/10.1016/S0142-9612(03)00482-4. PMid:14585707.

Cruz, A., Castro, W. A., Faria, J. A. F., Bolini, H. M. A., Celeghini, R. M. S., Raices, R. S. L., Oliveira, C. A. F., Freitas, M. Q., Conte, C. A. Jr., \& Mársico, E. T. (2013). Stability of probiotic yogurt added with glucose oxidase in plastic materials with different permeability oxygen rates during the refrigerated storage. Food Research International, 51(2), 723-728. http://dx.doi.org/10.1016/j.foodres.2013.01.028.

Fang, H., Huang, J., Ding, L., Li, M., \& Chen, Z. (2009). Preparation of magnetic chitosan nanoparticles and immobilization of laccase. Journal of Wuhan University of Technology-Materials Science Edition, 24(1), 42-47. http://dx.doi.org/10.1007/s11595-009-1042-7.

Franzreb, M., Siemann-Herzberg, M., Hobley, T. J., \& Thomas, O. R. T. (2006). Protein purification using magnetic adsorbent particles. Applied Microbiology and Biotechnology, 70(5), 505-516. http:// dx.doi.org/10.1007/s00253-006-0344-3. PMid:16496138.

Ghadi, A., Tabandeh, F., Mahjoub, S., Mohsenifar, A., Roshan, F. T., \& Alavije, R. (2015). Fabrication and characterization of core- shell magnetic chitosan nanoparticles as a novel carrier for immoblization of Burkholderia cepacia lipase. Journal of Oleo Science, 64(4), 423-430. http://dx.doi.org/10.5650/jos.ess14236. PMid:25833452.

Hecht, H. J., Kalisz, H. M., Hendle, J., Schmid, R. D., \& Schomburg, D. (1993). Crystal structure of glucose oxidase from Aspergillus niger refined at 2.3 Å resolution. Journal of Molecular Biology, 229(1), 153-172. http://dx.doi.org/10.1006/jmbi.1993.1015. PMid:8421298.

Huang, S. H., Liao, M. H., \& Chen, D. H. (2003). Direct binding and characterization of lipase onto magneticnanoparticles. Biotechnology Progress, 19(3), 1095-1100. http://dx.doi.org/10.1021/bp025587v. PMid:12790688.

Isik, S., Alkan, S., Toppare, L., Cianga, I., \& Yagci, Y. (2003). Immobilization of invertase and glucose oxidase inpoly 2-methylbutyl-2-(3-thienyl) acetate/polypyrrole matrices. Eurpoean Polym Journal, 39(12), 23752381. http://dx.doi.org/10.1016/S0014-3057(03)00184-8.

Jeong, U., Teng, X., Wang, Y., Yang, H., \& Xia, Y. (2007). Super paramagnetic colloids: controlled synthesis and niche applications. Advanced Materials, 19(1), 33-60. http://dx.doi.org/10.1002/adma.200600674.

Jiang, Y., Zhang, Q., Li, F., \& Niu, L. (2012). Glucose oxidase and grapheme bionanocomposite bridged by ionic liquid unit for glucose biosensing application. Sensors and Actuators. B, Chemical, 131(1), 728-733. http://dx.doi.org/10.1016/j.snb.2011.11.023.

Kaushik, A., Khan, R., Solanki, P. R., Pandey, P., Alam, J., Ahmad, S., \& Malhotra, B. D. (2008). Iron oxide nanoparticles-chitosan composite based glucose biosensor. Biosensors \& Bioelectronics, 24(4), 676683. http://dx.doi.org/10.1016/j.bios.2008.06.032. PMid:18692384.
Kim, M., Ham, H., Oh, S., Park, H., Chang, S., \& Choi, S. (2006). Immobilization of Mocur Javanicus lipase on effectively functionalized silica nanoparticles. Journal of Molecular Catalysis. B, Enzymatic, 39(1-4), 62-68. http://dx.doi.org/10.1016/j.molcatb.2006.01.028.

Laurent, S., Forge, D., Port, M., Roch, A., Robic, C., Vander Elst, L., \& Muller, R. N. (2008). Magnetic iron oxide nanoparticles: synthesis, stabilization, vectorization, physicochemical characterizations, and biological applications. Chemical Reviews, 108(6), 2064-2110. http:// dx.doi.org/10.1021/cr068445e. PMid:18543879.

Li, D., He, Q., Cui, Y., Duan, L., \& Li, J. (2007). Immobilization of glucose oxidase onto gold nanoparticles withenhanced thermostability. Biochemical and Biophysical Research Communications, 355(2), 488493. http://dx.doi.org/10.1016/j.bbrc.2007.01.183. PMid:17306226.

Liu, K., Zhao, G., He, B., Chen, L., \& Huang, L. (2012). Immobilization of pectinase and lipase on macroporous resin coated with chitosan for treatment of whitewater from papermaking. Bioresource Technology Journal, 123, 616-619. http://dx.doi.org/10.1016/j.biortech.2012.07.074. PMid:22947447.

Liu, Y., Jia, S., Wu, Q., Ran, J., Zhang, W., \& Wu, S. (2011). Studies of $\mathrm{Fe}_{3} \mathrm{O}_{4}$-chitosan nanoparticles prepared by co-precipitation under the magnetic field for lipase immoblization. Catalysis Communications, 12(8), 717-720. http://dx.doi.org/10.1016/j.catcom.2010.12.032.

Lu, A. H., Salabas, E. L., \& Schüth, F. (2007). Magnetic nanoparticles: synthesis, protection, functionalization, and application. Angewandte Chemie International Edition in English, 46(8), 1222-1244. http:// dx.doi.org/10.1002/anie.200602866. PMid:17278160.

Mi, F.-L., Kuan, C.-Y., Shyu, S.-S., Lee, S.-T., \& Chang, S.-F. (2000). Study of gelation kinetics and chain-relaxation properties of glutaraldehyde-cross-linked chitosan gel and their effects on microspheres preparation and drug release. Carbohydrate Polymers, 41(4), 389-396. http://dx.doi.org/10.1016/S0144-8617(99)00104-6.

Moon, J. S., Park, K. K., Kim, J. H., \& Seo, G. (2000). Reductive removal of dissolved oxygen in water byhydrazine over cobalt oxide catalyst supported on acti-vated carbon fiber. Applied Catalysis A, General, 201(1), 81-89. http://dx.doi.org/10.1016/S0926-860X(00)00423-3.

Osaka, T., Matsunaga, T., Nakanishi, T., Arakaki, A., Niwa, D., \& Iida, H. (2006). Synthesis of magnetic nanoparticles and their application to bioassays. Analytical and Bioanalytical Chemistry, 384(3), 593600. http://dx.doi.org/10.1007/s00216-005-0255-7. PMid:16402174.

Ramachandran, S., Fontanille, P., Pandey, A., \& Larroche, C. (2006). Gluconic acid: properties, applications and microbial production. Food Technology, 41, 748-755.

Sag, Y., \& Aktay, Y. (2002). Kinetic studies on sorption of Cr (VI) and $\mathrm{Cu}$ (II) ions by chitin, chitosan and Rhizopus arrhizus. Biochemical Engineering Journal, 12(2), 143-153. http://dx.doi.org/10.1016/ S1369-703X(02)00068-2.

Sheldon, R. A. (2007). Enzyme immobilization: the quest for optimum performance. Advanced Synthesis \& Catalysis, 349(8-9), 1289-1307. http://dx.doi.org/10.1002/adsc.200700082.

Shuler, M., \& Kargi, F. (2002). Bioprocess engineering: basic concepts (2nd ed.). Upper Sadle River: Prentice-Hall.

Van Amerongen, A., Barug, D., \& Lauwaars, M. (2005). Rapid methods for biological and chemical contaminants in food and feed. Wageningen: Wageningen Academic Publishers. http://dx.doi.org/10.3920/97890-8686-538-3.

Vasileva, N., \& Godjevargova, T. S. (2005). Study of the effect of some organic solvents on the activity andstability of glucose oxidase. Materials Science and Engineering C, 25(1), 17-21. http://dx.doi. org/10.1016/j.msec.2004.03.001.

Vikartovská, A., Bučko, M., Mislovičová, D., Pätoprstý, V., Lacík, I., \& Gemeiner, P. (2007). Improvement of the stability of glucose 
oxidase via encapsulation in sodium alginate-cellulose sulfate- poly (methylene- co- guanidine) capsules. Enzyme and Microbial Technology, 41(6-7), 748-755. http://dx.doi.org/10.1016/j.enzmictec.2007.06.010.

Yang, Y. M., Wang, J. W., \& Tan, R. X. (2004). Immobilization of glucose oxidase on chitosan-SiO2 gel. Enzyme and Microbial Technology, 34(2), 126-131. http://dx.doi.org/10.1016/j.enzmictec.2003.09.007.

Ying, L., Kang, E. T., \& Neoh, K. G. (2002). Covalent immobilization of glucose oxidase on mocroporousmembrane prepared from poly (vinylidene fluoride) with grafted poly (acrylic acid) side chains. Journal of Membrane Science, 208(1-2), 361-374. http://dx.doi. org/10.1016/S0376-7388(02)00325-3.

Zhu, H., Srivastava, R., Brown, J. Q., \& Mcshane, M. J. (2005). Combined physical and chemical immobilizationof glucose oxidase in alginate microspheres improves stability of encapsulation and activity. Bioconjugate Chemistry, 16(6), 1451-1458. http://dx.doi.org/10.1021/ bc050171z. PMid:16287241. 